\title{
PERMINTAAN GULA RAFINASI PADA INDUSTRI MAKANAN MINUMAN DAN FARMASI DI INDONESIA
}

\author{
The Demand for Refined Sugar in Food and Beverage and Pharmaceutical Industries \\ in Indonesia
}

\author{
Ainunnisa El Fajrin ${ }^{1}$, Slamet Hartono ${ }^{1}$, Lestari Rahayu Waluyati ${ }^{1}$ \\ ${ }^{1}$ Fakultas Pertanian Universitas Gadjah Mada
}

\begin{abstract}
The demand of food, beverage and pharmacuetical industries'products directly affected the demand of refined sugar. In Indonesia, refined sugar are fullfilled by local products from 11 refined sugar mills and imported products. The volume of imported refined sugar are suspected over capacity, so that there is a excess supply of refined sugar that leak into plantation white sugar market. It caused an unstable condition for plantation white sugar price. This research aims to determine the demand of refined sugar for food, beverage and pharmaceutical industries, then to forecast the demand for the next 10 years and also to determine the correlation between the volume of imported refined sugar and the white plantation sugar price. The method used is a multiple linear regression analysis, simple linear corellation analysis and trend analysis. This research used national data of large and medium industries from 1991 to 2012. The result shows that the factors affected refined sugar demand for food and pharmaceutical industries are world refined sugar prices, exchange rate, sugar beet prices and tariff. The factors affected refined sugar demand for beverage industries are sugar beet prices and tariff. The tendency of refined sugar demand in food, beverage and pharmaceutical industries for the next 10 years is increasing. There is also a positive correlation between volume of imported refined sugar and plantation white sugar prices for consumer.
\end{abstract}

Keywords: demand, refined sugar, industries

\section{INTISARI}

Permintaan terhadap produk yang dihasilkan industri makanan, minuman dan farmasi secara langsung akan memepengaruhi permintaan gula rafinasi. Gula rafinasi di Indonesia dicukupi dari produksi lokal oleh 11 PGR dan melalui impor langsung. Diduga saat ini volume impor gula rafinasi melebihi kebutuhan industri yang sebenarnya. Akibatnya terjadi surplus gula rafinasi yang merembes ke pasar GKP sehingga keseimbangan harga terganggu. Perlu adanya rekalkulasi kebutuhan gula rafinasi oleh industri agar tidak terjadi kelebihan stok yang merembes ke pasar GKP. Penelitian ini bertujuan untuk mengetahui permintaan gula rafinasi pada industi makanan, minuman dan farmasi, meramalkan kecenderungannya selama 10 tahun ke depan, dan mengetahui korelasi antara volume impor gula rafinasi dengan harga GKP di tingkat konsumen. Metode analisis yang digunakan adalah analisis regresi linier bergand, analisis korelasi linier sederhana, serta metode analisis trend. Penelitian terbatas pada industri sedang dan besar dengan data skala nasional tahun 1991 - 2012. Hasil penelitian menunjukkan bahwa faktor-faktor yang mempengaruhi permintaan gula rafinasi pada industri makanan dan farmasi adalah harga gula rafinasi dunia, nilai tukar rupiah, harga gula bit dan tarif impor. Sementara faktor-faktor yang mempengaruhi permintaan gula rafinasi pada industri minuman adalah harga gula bit dan tarif impor. Kecenderungan permintaan gula rafinasi pada industri makanan, minuman dan farmasi di Indonesia selama 10 tahun ke depan akan meningkat. Selain itu, ada korelasi positif antar volume impor gula rafinasi dengan harga GKP pada tingkat konsumen.

Kata kunci: permintaan, gula rafinasi, industri

\section{PENDAHULUAN}

Gula merupakan komoditas strategis bagi masyarakat Indonesia. Sebagai bahan pemanis utama, penggunaan gula masih belum dapat digantikan dengan sempurna oleh bahan pemanis lain. Secara umum penggunaan gula dibedakan menjadi dua, yaitu gula untuk konsumsi dan gula untuk industri. Gula untuk konsumsi sering kita kenal dengan nama Gula Kristal Putih (GKP), sedangkan gula untuk kebutuhan industri dikenal dengan nama gula rafinasi. Gula rafinasi diolah dari bahan baku gula mentah (raw sugar) yang melalui tahapan proses penyulingan, penyaringan, dan pembersihan lebih ketat dibandingkan dengan GKP. Tingkat kemurnian yang dimiliki gula rafinasi 
juga lebih tinggi, butiran kristal lebih halus, serta warna yang lebih putih. Atas pertimbangan kualitas tersebut, industri makanan, minuman, maupun farmasi lebih memilih gula rafinasi dibandingkan dengan GKP sebagai bahan baku industrinya.

Kebutuhan gula untuk industri, khususnya industri sedang dan besar dicukupi oleh gula rafinasi impor dan gula rafinasi lokal. Saat ini, terdapat 11 Pabrik Gula Rafinasi (PGR) yang beroperasi di Indonesia. Kesebelas pabrik tersebut memiliki kapasitas produksi yang berbeda-beda sehingga mampu memenuhi sebagian kebutuhan gula bagi industri. Namun, produksi gula rafinasi lokal belum mampu mencukupi seluruh permintaan industri sehingga masih dibutuhkan gula rafinasi impor.

Menurut Badan Pusat Statistik, impor yang dilakukan oleh Indonesia sebagian besar dalam bentuk bahan baku industri, yaitu berupa gula rafinasi maupun bahan bakunya, yaitu berupa raw sugar. Impor gula rafinasi yang dilakukan Indonesia disebabkan oleh karena tidak tercukupinya bahan baku pada tingkat lokal, khususnya secara kualitas. Pada pelaksanan impor, gula rafinasi (refined sugar) hasil industri yang dimiliki oleh importer gula kasar yang bersumber bahan bakunya berupa Gula Kristal Mentah/Gula Kasar (raw sugar) berasal dari impor hanya dapat diperjualbelikan atau didistribusikan kepada industri dan dilarang diperdagangkan ke pasar di dalam negeri (Direktorat Jenderal Perdagangan Luar Negeri, 2007).

Diduga pemerintah memberikan kuota izin impor gula rafinasi secara langsung melebihi kebutuhan yang ada. Saat ini seharusnya produksi gula rafinasi lokal mampu mengikis volume impor gula rafinasi oleh Indonesia. Pada kenyataannya bagi pihak-pihak tertentu, volume impor gula rafinasi masih terlalu tinggi, misalnya bagi para petani tebu yang tergabung dalam Asosiasi Petani Tebu Rakyat Indonesia (APTRI), akibatnya akhir-akhir ini dijumpai banyak gula rafinasi yang merembes ke pasar gula konsumsi. Kenampakan gula rafinasi yang lebih menarik serta harganya yang cenderung lebih murah di pasaran dibandingkan dengan GKP, membuat harga jual GKP anjlok. Harga gula rafinasu dijual di kisaran Rp 8.000-an hingga Rp 9.000-an per kg atau lebih murah dari harga gula non industri yang paling murah seharga $\mathrm{Rp}$ $10.000,00$ per kg (Anonim, 2014).

Penelitian ini bertujuan untuk mengetahui permintaan gula rafinasi pada industi makanan, minuman dan farmasi, meramalkan kecenderungannya selama 10 tahun ke depan, dan mengetahui korelasi antara volume impor gula rafinasi dengan harga GKP di tingkat konsumen.

\section{Teori Permintaan Faktor Produksi}

Permintaan akan faktor produksi, seperti halnya permintaan akan barang dan jasa, merupakan hubungan antara kuantitas faktor yang digunakan dan harga. Arti maksudnya, permintaan akan $x$ mewakili kuantitas $x$ yang diminta sebagai fungsi dari harganya sendiri, $r$, dan harga produk. Permintaan akan masukan merupakan permintaan yang diturunkan, karena fungsi tersebut tergantung pada harga produk dan diturunkan secara tak langsung dari permintaan akan produk (Beattie and Taylor, 1985).

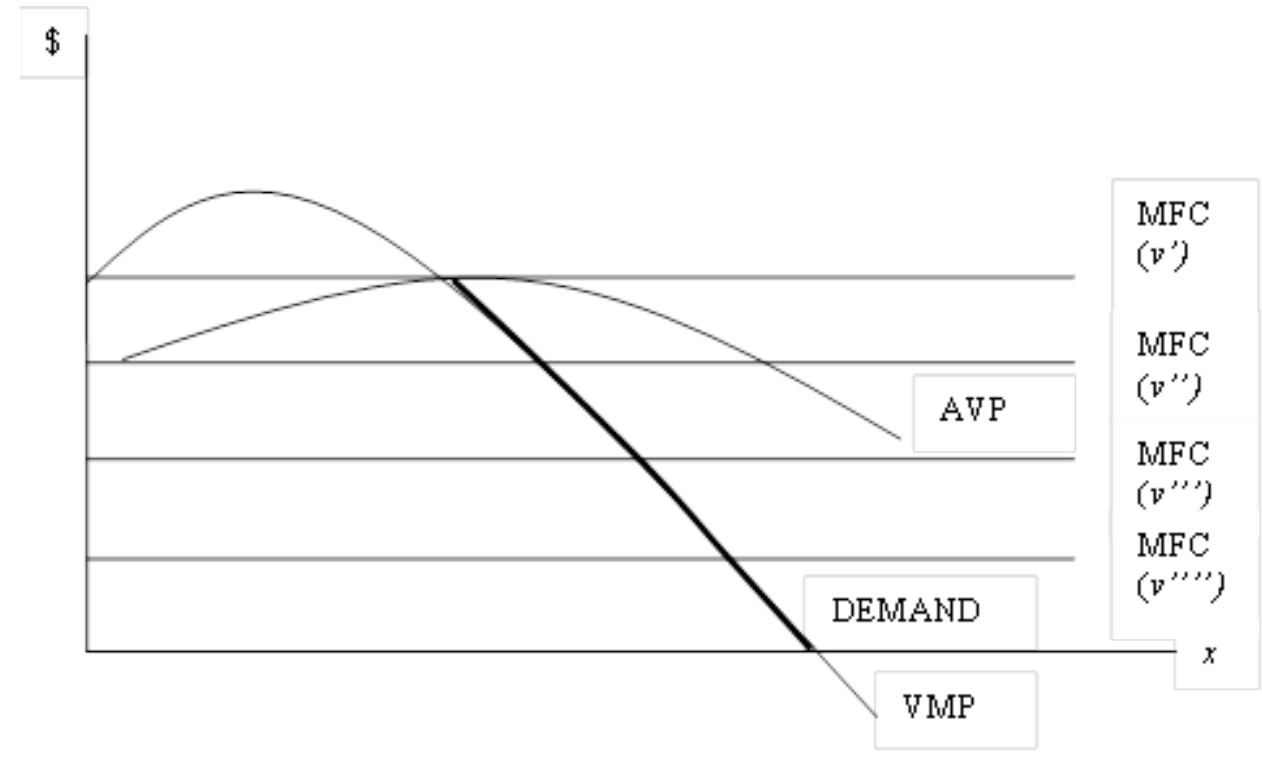

Gambar 1. Permintaan faktor produksi 
Menurut Debertin (1986), permintaan faktor produksi merupakan turunan atas permintaan konsumen. Permintaan terhadap faktor produksi dalam pertanian dipengaruhi oleh beberapa faktor, yaitu: (1) harga output, (2) harga input/faktor produksi, (3) harga faktor produksi lain dan (4) parameter fungsi produksi itu sendiri, misalnya elastisitas produksi masing-masing faktor produksi. Pada kondisi tertentu, jumlah faktor produksi lain dan ketersediaan dollar untuk membeli faktor produksi juga dapat mempengaruhi fungsi permintaan faktor produksi.

\section{Teori Peramalan}

Peramalan adalah suatu usaha untuk meramalkan keadaan di masa mendatang melalui pengujian keadaan di masa lalu. Esensi peramalan adalah perkiraan peristiwa-peristiwa di waktu yang akan datang atas dasar pola-pola di waktu yang lalu dan penggunaan kebijakan terhadap proyeksiproyeksi dengan pola-pola di waktu yang lalu. Proses peramalan biasanya terdiri dari langkahlangkah penentuan tujuan, pengembangan model, pengujian model, penerapan model, revisi dan evaluasi (Handoko, 2011).

Salah satu teknik peramalan yang sering digunakan adalah analisis runtun waktu (time series). Menurut Handoko (2011), komponen-komponen runtun waktu pada umumnya diklasifikasikan sebagai trend $(\mathrm{T})$, musiman atau seasional $(\mathrm{S})$, siklikal atau cyclical (C) dan residu atau erratic (E). Dalam model klasik analisis runtun waktu, nilai ramalan (Y) merupakan fungsi perkalian dari komponen-komponen tersebut:

$$
\mathrm{Y}=\mathrm{T} \times \mathrm{S} \times \mathrm{C} \times \mathrm{E}
$$

\section{Teori Perdagangan Internasional}

Perdagangan internasional identik dengan kegiatan ekspor dan impor yang dilakukan oleh suatu negara. Suatu negara akan mengekspor barang-barang yang apabila diproduksi sendiri akan menghabiskan sumberdaya yang lebih rendah dari negara lain. Sebaliknya, suatu negara akan mengimpor barang-barang yang apabila diproduksi sendiri akan menghabiskan sumberdaya yang lebih tinggi. Volume ekspor suatu komoditi dari negara tertentu ke negara lain merupakan selisih antara penawaran domestik dan permintaan domestik yang disebut sebagai kelebihan penawaran (excess supply). Pada pihak lain, kelebihan penawaran dari negara tersebut merupakan permintaan impor bagi negara lain atau merupakan kelebihan permintaan (excess demand).

\section{METODE PENELITIAN}

Metode dasar yang digunakan dalam penelitian ini adalah metode analisis deskriptif. Menurut Sugiyono (2009) metode analisis deskriptif merupakan metode yang bertujuan mendeskripsikan atau memberi gambaran terhadap suatu obyek penelitian yang diteliti melalui sampel atau data yang telah terkumpul dan membuat kesimpulan yang berlaku umum. Penelitian terbatas pada penggunaan data skala nasional dari tahun 1991

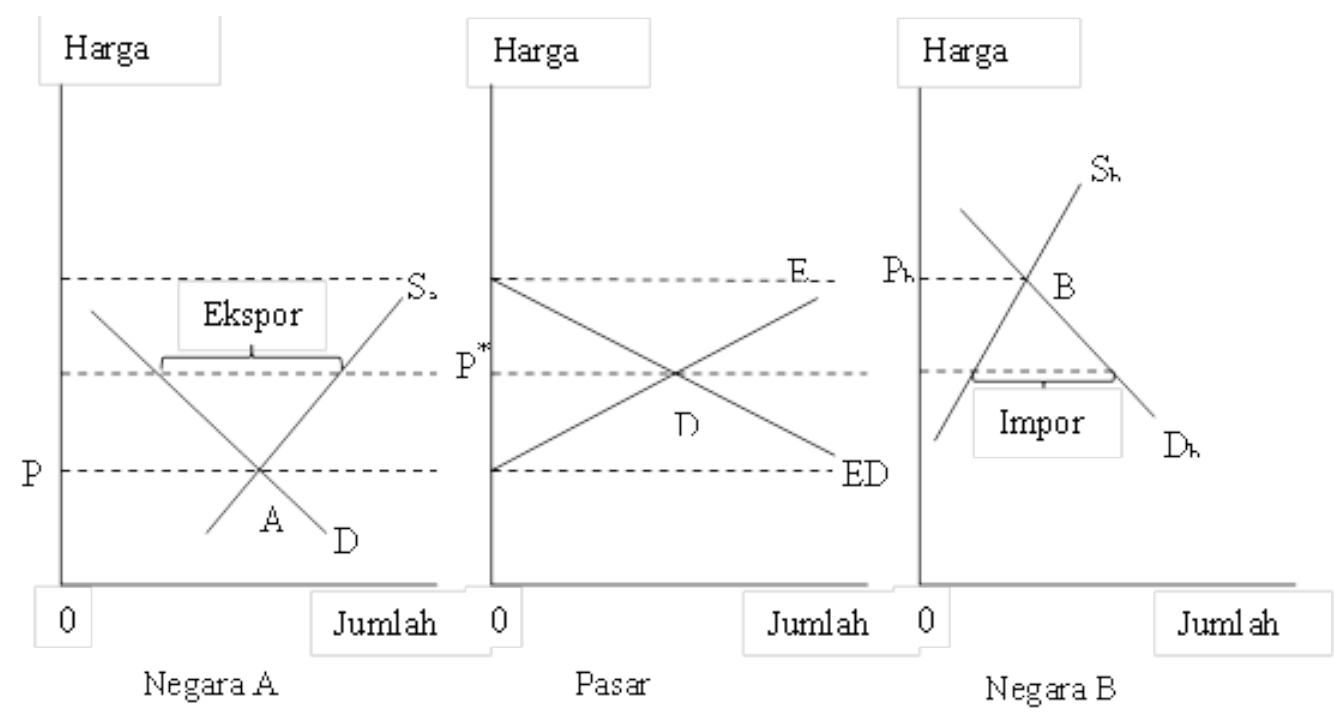

Gambar 2. Kurva Perdagangan Internasional Sumber: Salvatore (1997). 
- 2012. Industri yang dimaksud pada penelitian terbatas pada industri skala menengah dan besar.

\section{Analisis Permintaan}

Fungsi permintaan gula rafinasi pada penelitian ini diduga dipengaruhi oleh empat faktor, yaitu: harga gula rafinasi dunia, nilai tukar rupiah terhadap dollar, harga faktor produksi lain (gula bit) dan dummy tarif impor gula.

$$
\mathrm{LnY}=\mathrm{b}_{0}+\mathrm{b}_{1} \ln \mathrm{X}_{1}+\mathrm{b}_{2} \ln \mathrm{X}_{2}+\mathrm{b}_{3} \ln \mathrm{X}_{3}+\mathrm{d}_{1} \mathrm{D}_{1}+\mu
$$

\section{Keterangan:}

$\mathrm{Y} \quad=$ permintaan gula rafinasi pada industri makanan, minuman dan farmasi (ton)

$\mathrm{b}_{0} \quad=$ intersep

$\mathrm{b}_{1}-\mathrm{b}_{3}=$ koefisien regresi

$\mathrm{d}_{1} \quad=$ koefisien regresi variabel dummy

$\mathrm{X}_{1}=$ harga riil gula rafinasi dunia (US\$/ton)

$\mathrm{X}_{2}=$ nilai tukar riil rupiah terhadap dollar Amerika (Rp)

$\mathrm{X}_{3}=$ harga riil gula bit Amerika (US\$/ton)

$\mathrm{D}_{1} \quad=$ dummy tarif impor gula

$\mu \quad=$ faktor pengganggu lain

\section{Pengujian Model}

Pengujian model dilakukan dngan uji F, uji t, dan adjusted $\mathrm{R}^{2}$. Uji $\mathrm{F}$ digunakan untuk mengetahui pengaruh variabel independen secara bersamasama terhadap variabel dependen. Uji t digunakan untuk mengetahui hubungan masing-masing variabel independen secara individu terhadap variabel dependen. $\mathrm{R}^{2}$ atau koefisien determinasi merupakan besaran yang paling lazim digunakan untuk mengukur kebaikan atau kesesuaian garis regresi (goodness of fit). $\mathrm{R}^{2}$ memberikan proporsi atau presentase variasi total dalam variabel tak bebas $\mathrm{Y}$ yang dijelaskan oleh variabel yang menjelaskan (X) (Gujarati, 1999). Penggunaan $\mathrm{R}^{2}$ pada regresi linier berganda memiliki kelemahan, yaitu bias terhadap jumlah variabel independen yang ditambahkan, sehingga penggunaan $\mathrm{R}^{2}$ diganti dengan adjusted $\mathrm{R}^{2}$.

Estimator yang diguakan diharapkan telah berdistribusi normal dan bebas dari permasalahan asumsi klasik yang biasa terjadi pada analisis regresi linier berganda. Data yang telah lolos uji asumsi klasik dikatakan telah memenuhi syarat OLS yaitu BLUE (Best Linier Unbiassed Estimator).

\section{Analisis Korelasi}

Untuk mengetahui ada atau tidak ada korelasi antara volume impor gula rafinasi dengan harga gula pasir di Indonesia pada penelitian ini digunakan analisis korelasi linier sederhana. Analisis korelasi linier sederhana melibatkan dua variabel yaitu volume impor gula rafinasi dan harga gula pasir pada tingkat konsumen. Analisis korelasi linier sederhana digunakan untuk mengetahui keeratan hubungan antara dua variabel dan mengetahui bentuk hubungan yang terjadi. Koefisien korelasi menunjukkan seberapa besar hubungan yang terjadi antara dua variabel. Menghitung koefisien korelasi dapat dilakukan dengan rumus sebagai berikut:

$$
r=\frac{\sum \mathrm{x}_{\mathrm{i}} \mathrm{y}_{\mathrm{i}}}{\sqrt{\left(\sum \mathrm{x}_{\mathrm{i}}^{2}\right)\left(\sum \mathrm{y}_{\mathrm{i}}^{2}\right)}}
$$

Koefisien korelasi dapat bernilai positif atau negatif, terletak antara -1 dan $1(-1<\mathrm{r} \leq 1)$. Harianti et al., (2012) mengungkapkan, jika:

1) $0,2<\mathrm{r} \leq 0,4$ maka korelasi rendah/lemah

2) $0,4<\mathrm{r} \leq 0,7$ maka korelasi cukup berarti

3) $0,7<r \leq 0,9$ maka korelasi tinggi/kuat

4) $0,9<\mathrm{r}<1,0$ maka korelasi sangat tinggi/kuat sekali

5) $r=1$ maka korelasi sempurna

Hipotesis yang berlaku adalah sebagai berikut:

$\mathrm{H}_{0}: \mathrm{r}=0$, artinya antara variabel $\mathrm{X}$ dan $\mathrm{Y}$ saling independen

$\mathrm{H}_{1}: \mathrm{r} \neq 0$, artinya antara variabel $\mathrm{X}$ dan $\mathrm{Y}$ tidak saling independen

\section{Analisis Trend dan Peramalan Permintaan}

Metode yang digunakan adalah analisis trend. Bentuk persamaan yang digunakan untuk peramalan adalah sebagai berikut:

$$
\mathrm{Y}=\mathrm{a}+\mathrm{b} \mathrm{X}
$$

Keterangan:

$\mathrm{Y}=$ peramalan permintaan (ton)

$\mathrm{X}$ = kode yang menunjukkan variabel waktu

a $=$ intersep

$\mathrm{b}=$ koefisien regresi variabel $\mathrm{X}$ 


\section{HASIL DAN PEMBAHASAN}

Penelitian ini menganalisis faktor-faktor yang mempengaruhi permintaan gula rafinasi pada industri makanan, minuman dan farmasi di Indonsia, korelasi antara volum impor gula rafinasi dan harga gula kristal putih, serta meramalkan kecenderungan permintaan gula rafinasi pada ketiga industri tersebut selama 10 tahun mendatang.

\section{Faktor-faktor yang Mempengaruhi Permintaan Gula Rafinasi}

Permitaan ditunjukkan oleh banyaknya kebutuhan gula rafinasi pada idustri. Analisis permintaan dilakukan satu per satu pada ketiga industri dan secara agregat pada ketiganya.

\section{Industri Makanan}

Industri makanan pada penelitian ini terdiri atas industri pelumatan buah, pengalengan buah, susu, es krim, kecap, makanan dari cokelat dan kembang gula, sirop, roti kering, kue dan sejenisnya, kuekue basah, pengolahan teh dan kopi, serta kerupuk, keripik dan sejenisnya yang menggunakan gula rafinasi sebagai salah satu bahan baku produksinya. Dari hasil analisis diketahui nilai $\mathrm{F}$ hitung sebesar 14,670 . Sementara itu nilai $F$ tabel yang digunakan sebesar 3,608, maka dapat disimpulkan secara bersama-sama harga gula rafinasi, nilai tukar rupiah, harga gula bit dan dummy tarif impor berpengaruh signifikan terhadap permintaan gula rafinasi pada industri makanan di Indonesia. Diketahui nilai adjusted $\mathrm{R}$-square sebesar 0,722 ; artinya 72,20 persen keragaman pada variabel terikat mampu dijelaskan oleh keragaman pada variabel bebasnya, sisanya sebesar 27,80 persen dijelaskan oleh variabel lain di luar model. Hasil pada tabel 1 menunjukkan bahwa semua variabel bebas berpengaruh secara signifikan terhadap permintaan gula rafinasi pada industri makanan dengan tingkat kesalahan yang berbeda-beda.

\section{Industri Minuman}

Industri minuman pada penelitian ini terdiri dari kelompok industri minuman keras, minuman anggur dan minuman ringan. Nilai $\mathrm{F}$ hitung sebesar 3,806; lebih besar dari nilai $\mathrm{F}$ tabel sebesar 3,608, maka dapat disimpulkan secara bersama-sama harga gula rafinasi, nilai tukar rupiah, harga gula bit dan dummy tarif impor berpengaruh signifikan terhadap permintaan gula rafinasi pada industri minuman. Pada hasil uji $t$, hanya variabel harga gula bit dan dummy tarif impor yang masingmasing secara individu berpengaruh nyata terhadap permintaan gula rafinasi pada industri minuman di Indonesia. Persamaan yang dihasilkan memiliki nilai adjusted $\mathrm{R}$-squared sebesar 0,348 ; artinya 34,80 persen keragaman pada variabel permintaan gula rafinasi pada industri minuman di Indonesia mampu dijelaskan oleh variabel harga gula rafinasi, nilai tukar rupiah, harga gula bit dan dummy tarif impor, sisanya sebesar 65,20 persen dijelaskan oleh variabel-variabel lain di luar model.

\section{Industri Farmasi}

Industri farmasi pada penelitian ini meliputi industri bahan obat-obatan dan industri jamu.

Tabel 1. Fungsi Permintaan Gula Rafinasi pada Industri Makanan

\begin{tabular}{lcccc}
\hline \multicolumn{1}{c}{ Variabel } & Expected Sign & Koefisien & t-hitung & $\boldsymbol{\alpha}$ \\
\hline Konstanta & & $14,395^{* * *}$ & 17,655 & 0,000 \\
Harga Gula Rafinasi & - & $0,493^{* *}$ & 2,169 & 0,045 \\
Nilai Tukar Rupiah & - & $-1,352^{* *}$ & $-2,562$ & 0,020 \\
Harga Gula Bit & $+/-$ & $-0,338^{*}$ & $-2,046$ & 0,057 \\
Dummy Tarif Impor & - & $0,817^{* * *}$ & 6,458 & 0,000 \\
Adjusted R-squared & & & \multicolumn{2}{c}{0,722} \\
F-hitung & & & \multicolumn{2}{c}{14,670} \\
a F-hitung & & & \multicolumn{2}{c}{0,000} \\
\hline
\end{tabular}

Sumber: Analisis Data Sekunder, 2014

Keteragan:

*** signifikan pada tingkat kesalahan $1 \%(\alpha=0,010)$

** signifikan pada tingkat kesalahan 5\% $(\alpha=0,050)$

* $\quad$ signifikan pada tingkat kesalahan $10 \%(\alpha=0,100)$ 
Tabel 2. Fungsi Permintaan Gula Rafinasi pada Industri Minuman

\begin{tabular}{lccrc}
\hline \multicolumn{1}{c}{ Variabel } & Expected Sign & Koefisien & t-hitung & \multicolumn{1}{c}{$\boldsymbol{\alpha}$} \\
\hline Konstanta & & $13,474^{* * *}$ & 15,990 & 0,000 \\
Harga Gula Rafinasi & - & $0,362^{\text {ns }}$ & 1,542 & 0,142 \\
Nilai Tukar Rupiah & - & $-0,156^{\text {ns }}$ & $-0,286$ & 0,779 \\
Harga Gula Bit & +- & $-0,523^{* * *}$ & $-3,064$ & 0,007 \\
Dummy Tarif Impor & - & $0,287^{* *}$ & 2,195 & 0,042 \\
Adjusted R-squared & & & & 0,348 \\
F-hitung & & & 3,806 \\
$\alpha$ F-hitung & & & 0,022 \\
\hline
\end{tabular}

Sumber: Analisis Data Sekunder, 2014

Keteragan:

*** signifikan pada tingkat kesalahan 1\% $(\alpha=0,010)$

** $\quad$ signifikan pada tingkat kesalahan 5\% $(\alpha=0,050)$

* $\quad$ signifikan pada tingkat kesalahan $10 \%(\alpha=0,100)$

Tabel 3. Fungsi Permintaan Gula Rafinasi pada Industri Farmasi

\begin{tabular}{lcccr}
\hline \multicolumn{1}{c}{ Variabel } & $\begin{array}{c}\text { Expected } \\
\text { Sign }\end{array}$ & Koefisien & t-hitung & \multicolumn{1}{c}{} \\
\hline Konstanta & & $16,986^{* *}$ & 2,635 & 0,017 \\
Harga Gula Rafinasi & - & $3,605^{*}$ & 2,005 & 0,061 \\
Nilai Tukar Rupiah & - & $-7,276^{*}$ & $-1,743$ & 0,099 \\
Harga Gula Bit & $+/-$ & $-2,436^{*}$ & $-1,864$ & 0,080 \\
Dummy Tarif Impor & - & $6,174^{* * *}$ & 6,171 & 0,000 \\
Adjusted R-squared & & & & 0,689 \\
F-hitung & & & & 12,639 \\
a F-htung & & & & 0,000 \\
\hline
\end{tabular}

Sumber: Analisis Data Sekunder, 2014

Keteragan:

*** signifikan pada tingkat kesalahan $1 \%(\alpha=0,010)$

** $\quad$ signifikan pada tingkat kesalahan 5\% $(\alpha=0,050)$

* $\quad$ signifikan pada tingkat kesalahan $10 \%(\alpha=0,100)$

Diketahui bahwa nilai $\mathrm{F}$ hitung yang diperoleh sebesar 12,639 sementara nilai $\mathrm{F}$ tabel yang digunakan sebesar 3,608, maka dapat disimpulkan secara bersama-sama harga gula rafinasi, nilai tukar rupiah, harga gula bit dan dummy tarif impor berpengaruh signifikan terhadap permintaan gula rafinasi pada industri farmasi. Semua variabel bebas berpengaruh secara signifikan terhadap permintaan gula rafinasi pada industri makanan dengan tingkat kesalahan yang berbeda-beda. Pada tabel 3 diketahui nilai adjusted $\mathrm{R}$-squared persamaan regresi sebesar 0,689 ; artinya 68,90 persen keragaman varibael permintaan gula rafinasi pada industri farmasi di Indonesia mampu dijelaskan oleh keragaman variabel harga gula rafinasi, nilai tukar rupiah, harga gula bit dan dummy tarif impor, sisanya sebesar 31,10 persen dijelaskan oleh variabel lain di luar model.

\section{Gabungan Industri}

Data gabungan industri yang dimaksud pada penelitian ini data penjumlahan atau agregat dari permintaan gula rafinasi pada industri makanan, minuman dan farmasi di Indonesia. Ketiga industri merupakan industri yang tercatat memiliki kebutuhan gula rafinasi terbesar dibandingkan dengan kelompok industri lainnya. Hasil analisis regresi linier berganda menunjukkan bahwa model yang digunakan memiliki nilai $\mathrm{F}$ hitung sebesar 21,499 . Nilai $F$ tabel yang digunakan sebesar 3,729 sehingga secara bersama-sama variabel harga gula rafinasi, nilai tukar rupiah, harga gula bit dan dummy tarif impor berpengaruh signifikan terhadap permintaan gula rafinasi secara agregat pada industri makanan, minuman dan farmasi di Indonesia. Semua variabel bebas berpengaruh secara signifikan terhadap permintaan gula rafinasi pada industri makanan dengan tingkat kesalahan 
Tabel 4. Fungsi Permintaan Gula Rafinasi pada Gabungan Industri

\begin{tabular}{lccrr}
\hline \multicolumn{1}{c}{ Variabel } & Expected Sign & Koefisien & t-hitung & $\boldsymbol{\alpha}$ \\
\hline Konstanta & & $14,505^{* * *}$ & 22,087 & 0,000 \\
Harga Gula Rafinasi & - & $0,598^{* * *}$ & 3,142 & 0,007 \\
Nilai Tukar Rupiah & - & $-1,148^{* *}$ & $-2,722$ & 0,016 \\
Harga Gula Bit & +- & $-0,379^{* *}$ & $-2,827$ & 0,013 \\
Dummy Tarif Impor & - & $0,828^{* * *}$ & 7,749 & 0,000 \\
Adjusted R-squared & & & & 0,812 \\
F-hitung & & & & 21,499 \\
$\alpha$ F-hitung & & & & 0,000 \\
\hline
\end{tabular}

Sumber: Analisis Data Sekunder, 2014

Keteragan:

*** $\quad$ signifikan pada tingkat kesalahan $1 \%(\alpha=0,010)$

** $\quad$ signifikan pada tingkat kesalahan $5 \%(\alpha=0,050)$

* $\quad$ signifikan pada tingkat kesalahan $10 \%(\alpha=0,100)$

Tabel 5. Kebijakan Tarif Impor Gula (rafinasi) yang Berlaku di Indonesia

\begin{tabular}{|c|c|c|}
\hline Tahun & Peraturan yang Berlaku & $\begin{array}{l}\text { Tarif } \\
\text { Impor }\end{array}$ \\
\hline 2002 & $\begin{array}{l}\text { Kepmenkeu No.324/ } \\
\text { KMK.01/2002 }\end{array}$ & $\mathrm{Rp} \mathrm{700/kg}$ \\
\hline 2003 & $\begin{array}{l}\text { Kepmenkeu No.324/ } \\
\text { KMK.01/2002 }\end{array}$ & $\mathrm{Rp} 700 / \mathrm{kg}$ \\
\hline 2004 & $\begin{array}{l}\text { Kepmenkeu No.324/ } \\
\text { KMK.01/2002 }\end{array}$ & $\mathrm{Rp} 700 / \mathrm{kg}$ \\
\hline 2005 & $\begin{array}{l}\text { Permenkeu No.600/ } \\
\text { PMK.010/2004 }\end{array}$ & $\mathrm{Rp} 790 / \mathrm{kg}$ \\
\hline 2006 & $\begin{array}{l}\text { Permenkeu No.86/ } \\
\text { PMK.010/2005 }\end{array}$ & $\mathrm{Rp} 530 / \mathrm{kg}$ \\
\hline 2007 & $\begin{array}{l}\text { Permenkeu No.86/ } \\
\text { PMK.010/2005 }\end{array}$ & $\mathrm{Rp} 530 / \mathrm{kg}$ \\
\hline 2008 & $\begin{array}{l}\text { Permenkeu No.86/ } \\
\text { PMK.010/2005 }\end{array}$ & $\mathrm{Rp} 530 / \mathrm{kg}$ \\
\hline 2009 & $\begin{array}{l}\text { Permenkeu No.150/ } \\
\text { PMK.011/2009 }\end{array}$ & $\mathrm{Rp} 400 / \mathrm{kg}$ \\
\hline 2010 & $\begin{array}{l}\text { PermenkeuNo.239/ } \\
\text { PMK.011/2009 }\end{array}$ & $\mathrm{Rp} 790 / \mathrm{kg}$ \\
\hline 2011 & $\begin{array}{l}\text { Permenkeu No.239/ } \\
\text { PMK.011/2009 }\end{array}$ & $\mathrm{Rp} 790 / \mathrm{kg}$ \\
\hline 2012 & $\begin{array}{l}\text { Permenkeu No.239/ } \\
\text { PMK.011/2009 }\end{array}$ & $\mathrm{Rp} 790 / \mathrm{kg}$ \\
\hline
\end{tabular}

Sumber: Kementerian Keuangan, 2014

yang berbeda-beda. Persamaan regresi yang dihasilkan memiliki nilai adjusted $\mathrm{R}$-squared sebesar 0,812 ; artinya 81,20 persen keragaman pada variabel terikat mampu dijelaskan oleh keragaman pada variabel bebasnya. Sementara itu, sisanya sebesar 18,80 persen dijelaskan oleh variabel bebas lain di luar model.

Harga gula bit berpengaruh positif terhadap permintaan gula rafinasi, sehingga diasumsikan gula bit merupakan barang komplementer bagi gula rafinasi. Ketika harga gula bit meningkat, maka indusrti akan mengurangi volume permintaannya, diikuti dengan pengurangan volume permintaan gula rafinasi. Variabel dummy tarif impor dibagi menjadi dua, yaitu periode sebelum ada tarif impor spesifik (tahun 1991 - 2001) dan setelah ada tarif impor spesifik (tahun 2002 - 2012).

Hasil yang diperoleh tidak sesuai dengan hasil yang diharapkan, di mana adanya tarif impor akan menyebabkan penurunan permintaan gula rafinasi. Rendahnya tarif impor yang ditetapkan pemerintah Indonesia dibanding negara lain diduga menjadi penyebabnya. Alasan lain yang dapat menjelaskan ketidaksesuaian ini yaitu, dimungkinkan permintaan yang tetap meningkat dipenuhi oleh industri melalui produksi gula rafinasi lokal sehingga meskipun berlaku tarif impor, namun kebutuhannya masih dapat terpenuhi dengan memanfaatkan produksi dalam negeri.

\section{Pengaruh Impor Gula Rafinasi teradap Harga Gula Pasir}

Volume impor yang tidak sesuai dengan kebutuhan diduga telah mengganggu keseimbangan harga gula pasir di tingkat konsumen rumah tangga. Gula rafinasi yang tidak terserap oleh industri membanjiri pasar gula pasir dan muncul sebagai pesaing. Kenampakan fisik gula rafinasi yang lebih menarik dibanding gula pasir membuat konsumen awam lebih tertarik. Selain itu, gula rafinasi cenderung memiliki harga yang lebih murah karena diproses dengan teknologi yang lebih efisien, sedangkan mesin-mesin produksi pada 


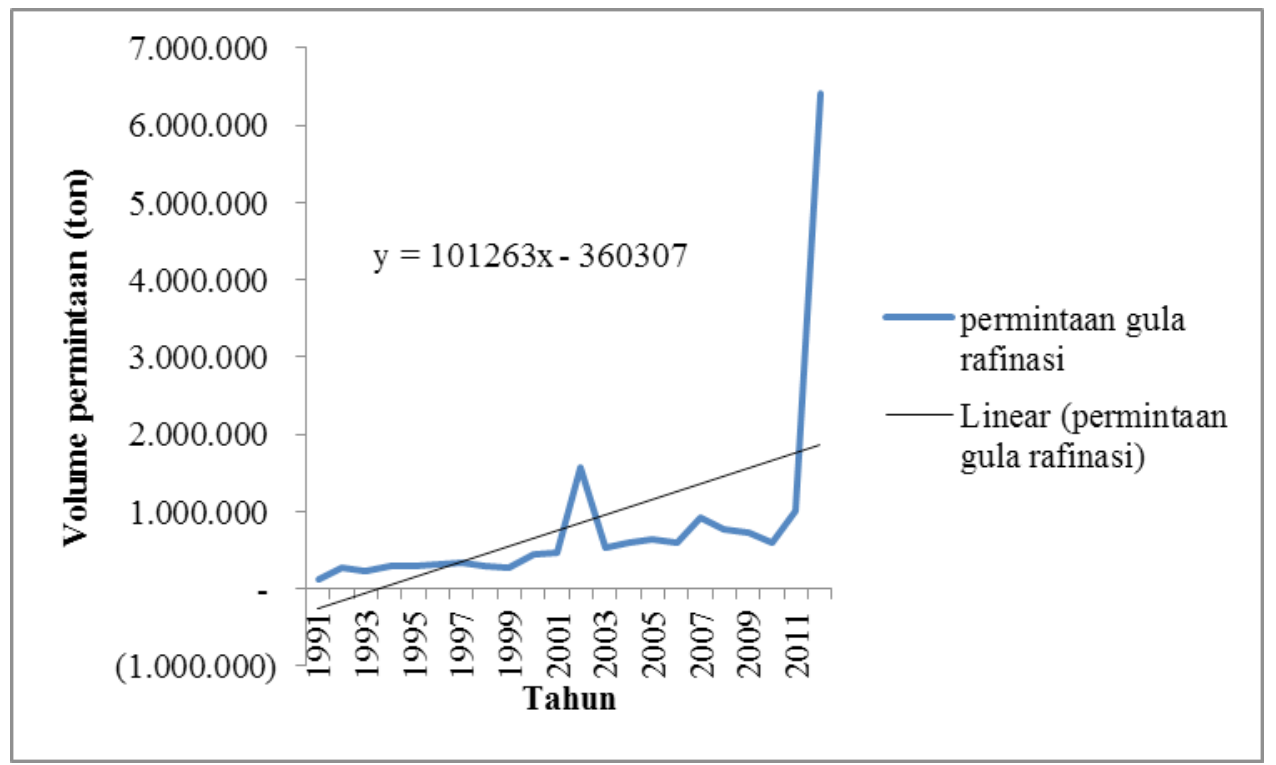

Gambar 3 Trend Permintaan Gula Rafinasi Tahun 1991 - 2012

pabrik gula biasa cenderung kurang efisien karena sudah beroperasi sejak zaman penjajahan Belanda. Akibatnya, harga gula pasir akan cenderung menyesuaikan harga gula rafinasi.

Penelitian ini bertujuan untuk mengetahui korelasi antara volume impor gula rafinasi dengan harga gula pasir di tingkat konsumen berdasar data dari tahun 1994 hingga 2012. Berdasarkan tabel 6 diperoleh nilai koefisien korelasi antara dua variabel yang digunakan sebesar 0,541. Angka ini menunjukkan ada hubungan korelasi yang cukup berarti antara volume impor gula rafinasi dengan harga gula pasir pada tingkat konsumen di Indonesia. Nilai signifikansi dari koefisien korelasi sebesar 0,017 atau lebih kecil dari 0,050. Dapat disimpulkan bahwa terdapat hubungan saling mempengaruhi antara volume impor gula rafinasi dengan harga gula pasir. Koefisien korelasi tidak menunjukkan hubungan sebab akibat. Koefisien korelasi yang bernilai positif menunjukkan bahwa ada hubungan antara kedua variabel yang digunakan. Dengan kata lain keduanya saling berpengaruh nyata atau tidak saling independen.

Tabel 6 Hasil Analisis Korelasi Volume Impor Gula Rafinasi dengan Harga Gula Pasir

\begin{tabular}{lr}
\hline \multicolumn{1}{c}{ Keterangan } & Value \\
\hline $\mathrm{N}$ & 19,000 \\
\hline Pearson Correlation & 0,541 \\
\hline$\alpha(2$-tailed) & 0,017 \\
\hline
\end{tabular}

Sumber: Analisis Data Sekunder, 2014
Hubungan yang terjadi adalah korelasi positif, di mana apabila terjadi peningkatan volume impor gula rafinasi, maka harga gula pasir pada tingkat konsumen akan cenderung meningkat. Hal ini tidak sesuai dengan hasil yang diharapkan maupun fakta yang ditemukan oleh APTRI di mana volume impor gula rafinasi yang melonjak menyebabkan rembesan gula rafinasi ke pasar gula konsumsi sehingga harga gula pasir mengalami penurunan. Ketidaksesuaian ini diakibatkan oleh karena ada faktor-faktor lain yang mempengaruhi harga gula pasir pada tingkat konsumen. Misalnya, harga gula dunia, harga lelang di tingkat petani dan produksi gula dalam negeri.

\section{Analisis Trend dan Peramalan Permintaan Gula Rafinasi}

Perhitungan trend dilakukan pada data volume permintaan gula rafinasi secara agregat oleh industri makanan, minuman dan farmasi di Indonesia pada tahun 1991 - 2012. Dengan menggunakan analisis trend variabel yang dianggap mempengaruhi permintaan masa yang akan datang hanya permintaan pada masa sebelumnya. Analisis trend yang dilakukan akan memproyeksikan permintaan gula rafinasi pada 10 tahun ke depan.

Diperoleh persamaan $\mathrm{y}=101.263 \mathrm{x}-$ 360.307 , pengujian terhadap data juga sudah dilakukan, variabel permintaan signifikan terhadap waktu dengan probabilitas t-hitung sebesar lebih kecil dari $\alpha(0,016<0,050)$. Persamaan trend tersebut mengindikasikan adanya kecenderungan 
meningkat terhadap permintaan gula rafinasi. Dengan persamaan ini dapat diramalkan permintaan gula rafinasi pada 10 tahun mendatang.

Tabel 7. Hasil Peramalan Permintaan Gula Rafinasi pada Industri Makanan, Minuman dan Farmasi di Indonesia

\begin{tabular}{cc}
\hline Tahun & Peramalan Permintaan (ton) \\
\hline 2015 & 2.373 .794 \\
2016 & 2.576 .320 \\
2017 & 2.778 .846 \\
2018 & 2.981 .372 \\
2019 & 3.183 .898 \\
2020 & 3.386 .424 \\
2021 & 3.588 .950 \\
2022 & 3.791 .476 \\
2023 & 3.994 .002 \\
2024 & 4.196 .528 \\
\hline
\end{tabular}

Sumber: Analisis Data Sekunder, 2014

Hasil peramalan mengindikasikan adanya peningkatan permintaan gula rafinasi secara agregat pada industri makanan, minuman dan farmasi di Indonesia dalam kurun waktu 10 tahun mendatang. Dengan mengabaikan faktor-faktor lain kecuali permintaan tahun sebelumnya, permintaan gula rafinasi secara agregat pada industri makanan, minuman dan farmasi di Indonesia akan cenderung meningkat. Permintaan yang semakin meningkat harus diimbangi dengan ketersediaan gula rafinasi yang juga meningkat, terutama gula rafinasi dalam negeri.

\section{KESIMPULAN}

1. Faktor-faktor yang mempengaruhi permintaan gula rafinasi pada industri makanan di Indonesia adalah harga gula rafinasi, nilai tukar rupiah, harga gula bit dan tarif impor.

2. Faktor-faktor yang mempengaruhi permintaan gula rafinasi pada industri minuman di Indonesia adalah harga gula bit dan tarif impor.

3. Faktor-faktor yang mempengaruhi permintaan gula rafinasi pada industri farmasi di Indonesia adalah harga gula rafinasi, nilai tukar rupiah, harga gula bit dan tarif impor.

4. Faktor-faktor yang mempengaruhi permintaan gula rafinasi secara agregat pada industri makanan, minuman dan farmasi di Indonesia adalah harga gula rafinasi, nilai tukar rupiah, harga gula bit dan tarif impor.
5. Ada korelasi positif antara volume impor gula rafinasi dengan harga gula pasir (GKP) pada tingkat konsumen di Indonesia.

6. Permintaan gula rafinasi secara agregat oleh industri makanan, minuman dan farmasi di Indonesia memiliki kecenderungan meningkat setiap tahunnya. Hasil peramalan menunjukkan permintaan gula rafinasi akan terus meningkat lebih kurang 202.526 ton pada tahun-tahun berikutnya.

\section{DAFTAR PUSTAKA}

Arief, S. 1996. Teori Ekonomi Mikro dan Makro Lanjutan. PT Raja Grafindo Persada, Jakarta.

Beattie, B. R., and C. R. Taylor. 1985. The Economics of Production (Ekonomi Produksi), alih bahasa: S. Josohardjono dan G. Sumodiningrat. Edisi pertama. Gadjah Mada University Press, Yogyakarta.

Dachliani, D. M. 2006. Permintaan Impor Gula Indonesia Tahun 1980 - 2003. UNiversitaS Diponegoro. Tesis.

Daniel, M. 2002. Pengantar Ekonomi Pertanian. PT Bumi Aksara, Jakarta.

Debertin, D. L. 1986. Agricultural Production Economics. Macmillan Publishing Company, New York.

Direktorat Jenderal Perdagangan Luar Negeri. 2007. Kebijakan Umum di Bidang Impor. Departemen Perdagangan, Jakarta.

Direktorat Jenderal Industri Agro. 2013. Kebijakan Pengembangan Industri Gula Rafinasi. Kementerian Perindustrian, Jakarta.

Gujarati, D. 1999. Basic Econometrics (Ekonomimetrika Dasar), alih bahasa: S. Zain. Penerbit Erlangga, Jakarta.

Handoko, T. H. 2011. Dasar-dasar Manajemen Produksi dan Operasi. Edisi Pertama. Cetakan Keenambelas. BPFE UGM, Yogyakarta.

Salvatore, D. 1997. Ekonomi Internasional. Edisi Kelima Jilid 1, alih bahasa: H. Munandar. Penerbit Erlangga, Jakarta.

Sugiyono. 2009. Metode Penelitian Bisnis (Pendekatan Kuantitatif, Kualitatif dan R\&D). Penerbit Alfabeta, Bandung.

Teguh, M. 1999. Metodologi Penelitian Ekonomi, Teori dan Aplikasi. PT Raja Grafindo Persada, Jakarta. 